Industrial Health, 1981, 19, 115.

\title{
DETERMINATION OF TRIETHYLLEAD, DIETHYLLEAD AND INORGANIC LEAD IONS IN URINE BY HYDRIDE GENERATION-FLAMELESS ATOMIC ABSORPTION SPECTROMETRY
}

\author{
Hiroshi YAMAUCHI, Fumio ARAI and Yukio YAMAMURA \\ Department of Public Health, St. Marianna University School of \\ Medicine, 2095 Sugao, Takatsu-ku, Karwasaki 213 Japan
}

(Received February 3, 1981)

\begin{abstract}
A technique utilizing hydride generation-atomic absorption spectrophotometry was established for the fractional determination of triethyllead $\left(\mathrm{Et}_{3} \mathrm{~Pb}^{+}\right)$, diethyllead $\left(\mathrm{Et}_{2} \mathrm{~Pb}^{2+}\right)$, inorganic lead $\left(\mathrm{Pb}^{2+}\right)$ and total lead (total $\mathrm{Pb}$ ) in the urine.

The extraction of the target lead compounds from the urine required the pretreatment of urine samples.

Sample solutions were prepared by the use of $0.5 \mathrm{M}$ DL-Malic acid for the generation of $\mathrm{Et}_{3} \mathrm{~Pb}^{+}$, by the use of $0.75 \mathrm{M} \mathrm{H}_{2} \mathrm{O}_{2}-0.004 \mathrm{M} \mathrm{HClO}_{4}$ for the generation of $\mathrm{Et}_{2} \mathrm{~Pb}^{2+}$, and by the use of $1.6 \mathrm{M}$ DL-Malic acid- $0.05 \mathrm{M} \mathrm{K}_{2} \mathrm{Cr}_{2} \mathrm{O}_{7}$ for the generation of $\mathrm{Pb}^{2+}$; and sodium borohydride was then added to the so treated sample solutions. The lead hydrides were once fixed in a U-trap cooled with liquid nitrogen beforehand, and the respective hydrides were then fractionated by volatization; and the fractions were atomized in a quartz cell heated to $1000^{\circ} \mathrm{C}$ for atomic absorption spectrophotometry.

The recovery rates by this technique from 5 replications proved to be $99.7 \%$ for $\mathrm{Et}_{3} \mathrm{~Pb}^{+}, 97.3 \%$ for $\mathrm{Et}_{2} \mathrm{~Pb}^{2+}, 91.4 \%$ for $\mathrm{Pb}^{2+}$, and $95.9 \%$ for total $\mathrm{Pb}$, with the coefficients of variation being $5.6 \%$ for $\mathrm{Et}^{2} \mathrm{~Pb}^{+}, 7.5 \%$ for $\mathrm{Et}_{2} \mathrm{~Pb}^{2+}, 2.1 \%$ for $\mathrm{Pb}^{2+}$ and $2.9 \%$ for total $\mathbf{P b}$. The detection limits of this technique also proved to be 0.005 $\mu \mathrm{gPb}$ for $\mathrm{Et}^{3} \mathrm{~Pb}^{+}$and $\mathrm{Et}_{2} \mathrm{~Pb}^{2+}$ and $0.1 \mu \mathrm{gPb}$ for $\mathrm{Pb}^{2+}$.
\end{abstract}

Keywords: Atomic absorption spectrophotometry-Hydride generation-Human urineTriethyllead-Diethyllead-Inorganic lead

\section{INTRODUCTION}

Tetraethyllead is known to be degraded into diethyllead via triethyllead and further into inorganic lead through physical and chemical actions in Nature $;^{1)}$ and similar degradation of this compound can presumably take place in vivo. ${ }^{2}$ This fact means that the determination of triethyllead $\left(\mathrm{Et} 3 \mathrm{~Pb}^{+}\right)$, diethyllead $\left(\mathrm{Et}_{2} \mathrm{~Pb}^{2+}\right)$ and inorganic lead $\left(\mathrm{Pb}^{2+}\right)$ in the urine and blood is indispensable for assessment of the severity of tetraethyllead poisoning or biological monitoring of workers at lead processing plants. 


\section{H. YAMAUCHI, F. ARAI AND Y. YAMAMURA}

Colorimeteric methods for the determination of triethyllead have been reported by Henderson and Snyder ${ }^{3)}$ (1961), Bolanowska ${ }^{4)}$ (1968) and Imura et al.,5) (1971) and there are also established microanalytical methods utilizing gas chromatography. ${ }^{6}$ Besides, there are a few reports of colorimetric analysis for diethyllead. ${ }^{377}$ However, it has been found considerably difficult to apply these colorimetric methods for the analysis of not a few biological samples because of their poor sensitivities.

In the last few years, analytical methods for arsenic ${ }^{8)}$ and $\operatorname{tin}^{9)}$ by means of hydride generation have been presented, making it possible to fractionate different chemical species of metal compounds and determine them with high sensitivities. The present authors ${ }^{1011)}$ have determined different chemical species of arsenic compounds in biological samples. Furthermore, Jin et al. ${ }^{12)}$ (1978) have reported an analytical method for inorganic lead utilizing hydride generation.

The present paper offers an improvement on the analytical method for arsenic previously developed by the authors ${ }^{10)}$ so as to be suitable for the determination of lead, which, as the result of a study of its conditions for the determination of $\mathrm{Et} 3 \mathrm{~Pb}^{+}, \mathrm{Et} 2 \mathrm{~Pb}^{2+}$ and $\mathrm{Pb}^{2+}$, has proved capable of determining these lead compounds in the urine with high sensitivities by the use of the same system.

\section{Apparatus and Reagents}

\section{Apparatus}

The Shimadzu model AA-610S atomic absorption spectrophotometer was used for atomic absorption spectrophotometry. The Hamamatsu TV Co. hollow cathode lamp was used as the lead light source (2833A). The manifolds for the generation, fixation and atomization of lead hydrides are illustrated in Fig. 1. The U-trap for the fixation

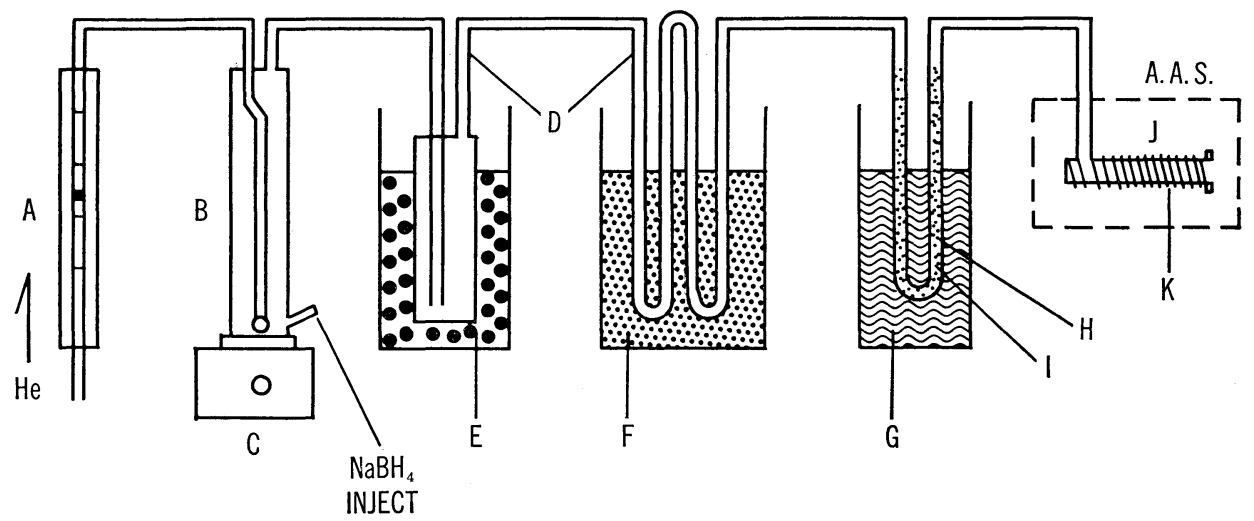

Fig. 1. Sample reaction chamber, U-trap and detector arrangement.
A : gas flow meter,
$\mathrm{B}$ : generator,
$\mathrm{C}$ : magnet mixer,
D: water trap,
E : ice
$\mathrm{F}:$ ice $+\mathrm{NaCl}$,
$\mathrm{G}$ : liquid $\mathrm{N}_{2}$,
$\mathrm{H}$ : U-trap, I: quartz wool, $\mathrm{J}:$ quartz cell, $\mathrm{K}:$ nichrome wire 


\section{DETERMINATION OF ETHYLLEAD COMPOUNDS BY HYDRIDE GENERATION}

and volatization of lead hydrides was a quartz tube $5 \mathrm{~mm}$ in caliber, $7 \mathrm{~mm}$ in external diameter, and $200 \mathrm{~mm}$ in height, packed homogeneously with quartz wool. The quartz cell for the atomization of lead hydrides was $10 \mathrm{~mm}$ in caliber, $14 \mathrm{~mm}$ in external diameter, and $140 \mathrm{~mm}$ in length. A nichrome wire was used for heating the quartz cell to $1,000^{\circ} \mathrm{C}$.

\section{Reagents}

Working standard solution of Et3Pb+: Triethyllead chloride (Alfa Division, Ventron Corp., U.S.A.) was purified with water-alcohol. The lead content of the purified triethyllead chloride was $98 \%$ of the theoretical value. This product contained not more than $0.1 \%$ inorganic lead, ${ }^{\left.13{ }^{14}\right)}$ and no diethyllead ions) (not more than $0.1 \%$ ); and $3.30 \mathrm{mg}$ of this compound was dissolved in $100 \mathrm{ml}$ of water.

Working standard solution of $\mathrm{Et}_{2} \mathrm{~Pb}^{2+}$ : Diethyllead dichloride was synthesized from tetraethyllead (Strem Chemicals Inc., U.S.A.) via diethyllead dibenzoate by Heap's method, ${ }^{13}$ ) and purified with water-alcohol. The lead content of the purified diethyllead dichloride was $99 \%$ of the theoretical content. This purified product contained $0.3 \%$ inorganic lead and no triethyllead ions (not more than $0.1 \%)^{5)}$; and $3.35 \mathrm{mg}$ of this purified compound was dissolved in $100 \mathrm{ml}$ of water.

Working standard solution of $\mathrm{Pb}^{2+}$ : This solution was prepared by dissolving $100 \mathrm{mg}$ of metal lead (purity: 99.99\% ; Soekawa Chemical Co., Ltd., Tokyo) in $100 \mathrm{~m} l$ of $1 \mathrm{~N} \mathrm{HNO}_{3}$.

These 3 working standard solutions were diluted properly before use.

$10 \% \mathrm{w} / \mathrm{v}$ solution of sodium borohydride $\left(\mathrm{NaBH}_{4}\right)$ : After $1 \mathrm{~N} \mathrm{NaOH}$ solution (E. Merck AG, West Germany) had been adjusted to $0.2 \mathrm{~N}, \mathrm{NaBH}_{4}$ was dissolved in this solution. This $\mathrm{NaBH}_{4}$ solution was prepared before use.

Glyoxal-bis(2-hydroxy-anil) solution ${ }^{7)}$ (GHA): This solution was prepared by dissolving $0.24 \mathrm{~g}$ of dotite GHA (Dojindo Co., Ltd., Kumamoto) in $100 \mathrm{ml}$ of methanol; and the solution was allowed to stand at room temperature, kept from light, for 24 hours before use.

The acids used were all reagents of super special grade, and all the other reagents were of special grade. Water was subjected to ion exchange after distillation.

\section{Procedure}

The working standard solutions of lead compounds $\left(\mathrm{Et}^{3} \mathrm{~Pb}^{+}, \mathrm{Et}_{2} \mathrm{~Pb}^{2+}\right.$ and $\left.\mathrm{Pb}^{2+}\right)$ or a sample (containing not more than $1 \mu \mathrm{g}$ as $\mathrm{Pb}$ ) was transferred into the sample reaction chamber, and one of 3 different buffers (Figs. 3, 4 and 5) was added at a time. The reaction solution was kept to a constant volume. Helium gas was allowed to flow through the chamber at the flow rate of 5 liters/minute to replace the air in it completely. Then, $2 \mathrm{ml}$ of $10 \% \mathrm{NaBH}_{4}$ was added into the sample reaction chamber while cooling the U-trap with liquid nitrogen, and allowed to react for 2 to 5 minutes. The lead hydrides generated in this reaction were fixed to the quartz wool in the U-trap. After the end of the reaction, the U-trap was warmed to room temperature; the lead hydrides 


\section{H. YAMAUCHI, F. ARAI AND Y. YAMAMURA}

were then volatized; the lead hydrides so fractionated were atomized in the quartz cell heated to $1,000^{\circ} \mathrm{C}$, respectively, and determined with the atomic absorption spectrophotometer. This procedure gave the peaks of lead hydrides illustrated in Fig. 2.

\section{Results AND Discussion}

1. Conditions of buffers for $E t 3 P b^{+}, E t 2 P b^{2+}$ and $\mathrm{Pb}^{2+}$

Sodium borohydride, acids and oxidizing agents are indispensable for the conversion of leads into their hydrides. Therefore, the acids and oxidizing agents suitable for

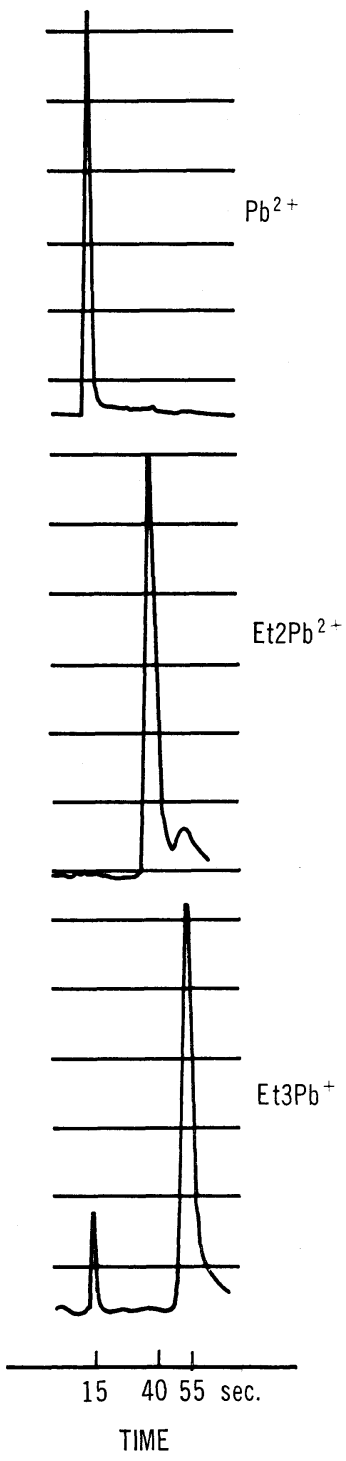

Fig. 2. Corrected retention time of leads. 


\section{DETERMINATION OF ETHYLLEAD COMPOUNDS BY HYDRIDE GENERATION}

analysis of the respective leads were investigated.

\section{1-1. $E t 3 P b^{+}$}

DL-Malic acid buffers were used for the determination of $\mathrm{Et}_{\mathrm{t}} \mathrm{Pb}^{+}$. As illustrated in Fig. 3, DL-malic acid buffers at not less than $0.4 \mathrm{M}$ proved to give a constant high sensitivity; and $0.5 \mathrm{M}$ DL-malic acid buffer was used in the subsequent experiments. The reaction solution required stirring with a magnetic stirrer for not less than 2 minutes.

\section{1-2. $E t 2 P b^{2+}$}

The $\mathrm{HClO}_{4}$ and $\mathrm{H}_{2} \mathrm{O}_{2}$ system was used for the determination of $\mathrm{Et}_{2} \mathrm{~Pb}^{2+}$. As depicted in Fig. 4, absorption spectrophotometry was performed by varying the concentration of $\mathrm{H}_{2} \mathrm{O}_{2}$ while maintaining the $\mathrm{HClO}_{4}$ solution at $0.004 \mathrm{M}$. As a result, it was shown that maximum sensitivity was attained with $\mathrm{H}_{2} \mathrm{O}_{2}$ at $0.75 \mathrm{M}$. Then, the concentration of $\mathrm{HClO}_{4}$ was raised while $\mathrm{H}_{2} \mathrm{O}_{2}$ was maintained at $0.75 \mathrm{M}$ : this experiment proved that the sensitivity was greatly improved, but it was associated with the degradation of

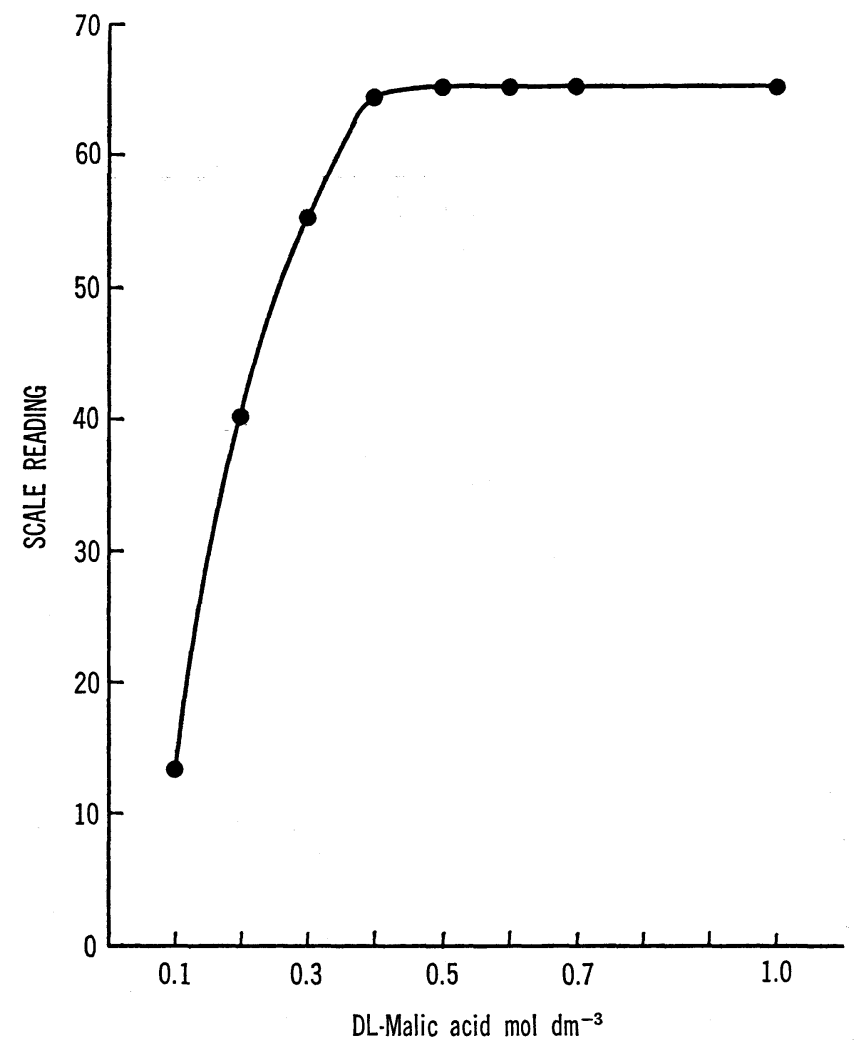

Fig. 3. Effect of D, L-Malic acid concentration on sensitivity to triethyllead.

1) $\mathrm{Et}_{3} \mathrm{~Pb}^{+} ; 0.1 \mu \mathrm{g} \mathrm{Pb}$

2) $10 \% \mathrm{w} / \mathrm{v} \mathrm{NaBH} 42 \mathrm{ml}$ 


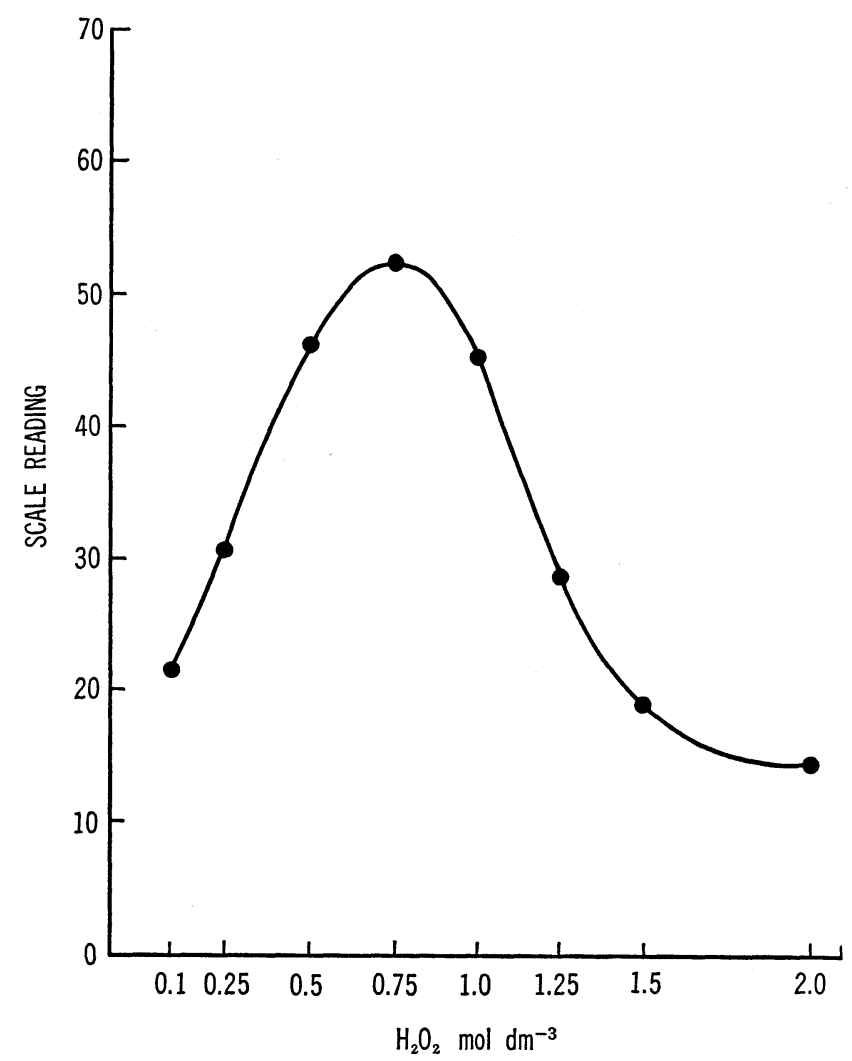

Fig. 4. Effect of hydrogen peroxide concentration on sensitivity to diethyllead.

1) $\mathrm{Et}_{2} \mathrm{~Pb}^{2+} ; 0.1 \mu \mathrm{g} \mathrm{Pb}$

2) $0.004 \mathrm{M} \mathrm{HClO}_{4}$

3) $10 \% \mathrm{w} / \mathrm{v} \mathrm{NaBH} 42 \mathrm{~m} l$

Et2 $2 \mathrm{~Pb}^{2+}$. For this reason, the concentration of $\mathrm{HClO}_{4}$ was decided to be $0.004 \mathrm{M}$. The reaction by the use of this system required 5 minutes.

\section{1-3. $P b^{2+}$}

$\mathrm{Pb}^{2+}$ was determined by the use of the DL-malic acid and $\mathrm{K}_{2} \mathrm{Cr}_{2} \mathrm{O}_{7}$ system. As illustrated in Fig. 5, the concentration of $\mathrm{K}_{2} \mathrm{Cr}_{2} \mathrm{O}_{7}$ was varied while DL-malic acid was maintained at $1.6 \mathrm{M}$. This experiment showed that maximum sensitivity was attained with the concentration of $\mathrm{K}_{2} \mathrm{Cr}_{2} \mathrm{O}_{7}$ between 0.05 and $0.06 \mathrm{M}$. The reaction by the use of this system required 2 minutes.

\section{Influences of coexistent metal ions}

Table 1 shows the influences of coexistent metal ions on the determination of $\mathrm{Et}^{3} \mathrm{~Pb}^{+}$, $\mathrm{Et} 2 \mathrm{~Pb}^{2+}$ and $\mathrm{Pb}^{2+}$.

It was found that $\mathrm{Ag}^{+}$and $\mathrm{Cu}^{2+}$ were the potent interfering ions for the determination of $\mathrm{Et} 3 \mathrm{~Pb}^{+} ; \mathrm{Ag}^{+}, \mathrm{Co}^{2+}, \mathrm{Cr}^{6+}$ and $\mathrm{Cu}^{2+}$, for the determination of $\mathrm{Et}_{2} \mathrm{~Pb}^{2+}$, and $\mathrm{Co}^{2+}$ 


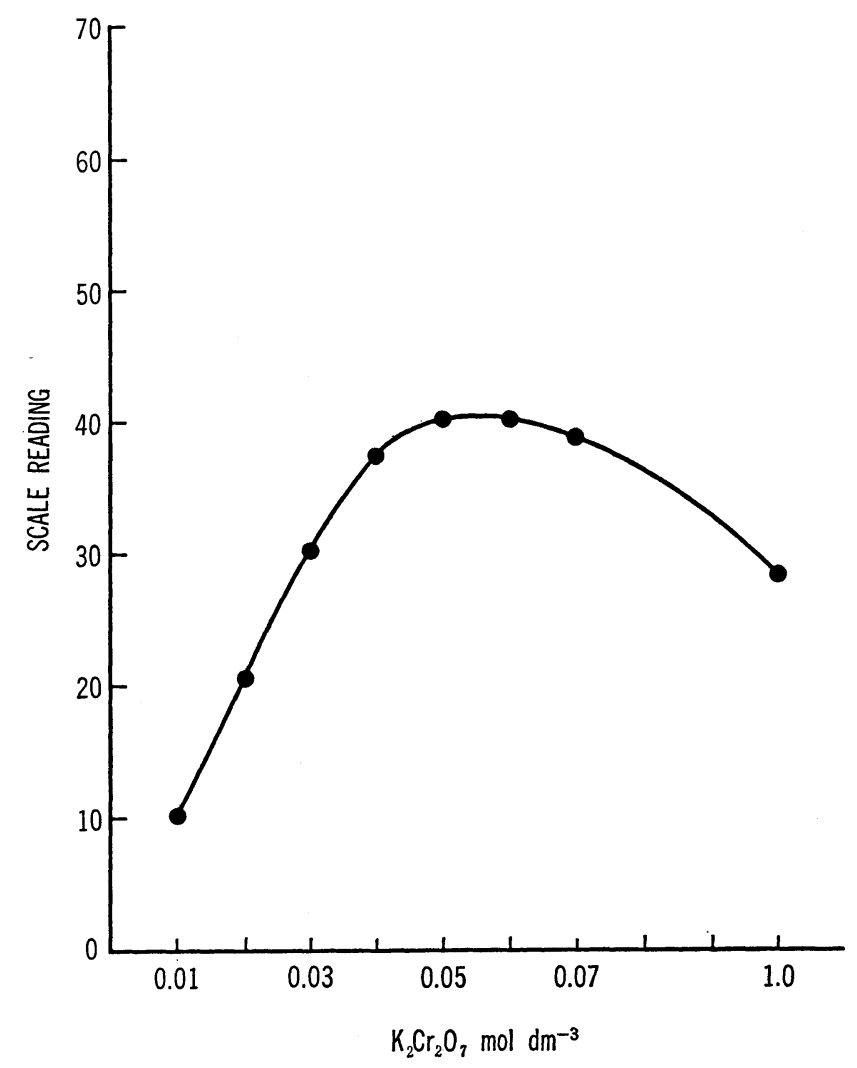

Fig. 5. Effect of potassium dichromate concentration on sensitivity to inorganic lead.

1) $\mathrm{Pb}^{2+} ; 0.1 \mu \mathrm{g} \mathrm{Pb}$

2) $1.6 \mathrm{M} \mathrm{D}$, L-Malic acid

3) $10 \% \mathrm{w} / \mathrm{v} \mathrm{NaBH} \mathrm{N}_{4} 2 \mathrm{~m} l$

and $\mathrm{Mn}^{2+}$, for the determination of $\mathrm{Pb}^{2+}$.

3. Methods for extraction of $\mathrm{Et}_{3} \mathrm{~Pb}^{+}, \mathrm{Et} 2 \mathrm{~Pb}^{2+}$ and $\mathrm{Pb}^{2+}$ from the urine

The direct determination of total lead in the urine is possible. However, the direct determination of $\mathrm{Et} 3 \mathrm{~Pb}^{+}, \mathrm{Et} 2 \mathrm{~Pb}^{2+}$ and $\mathrm{Pb}^{2+}$ required the pretreatment by the following extraction procedures for the interference by the organic substances and inorganic ions present in the urine, while the direct determination of $\mathrm{Et}^{3 \mathrm{~Pb}^{+}}$in the fresh urine is possible.

\section{3-1. Et $3 P b^{+}$in the urine}

After $20 \mathrm{~m} l$ of a urine sample was measured into a glass-stoppered centrifuge tube, $4 \mathrm{ml}$ of $60 \% \mathrm{HClO}_{4}, 8 \mathrm{~g}$ of $\mathrm{NaCl}$ and $10 \mathrm{ml}$ of benzene were added into the tube, and the contents were shaken vigorously for 20 minutes. The tube was then centrifuged at 3,000 r.p.m. for 20 minutes. The benzene layer separated in the top layer was transferred into a separating funnel, and the $\mathrm{Et}_{\mathrm{t}} \mathrm{Pb}^{+}$in the layer was back-extracted into $1 \%$ 
H. YAMAUCHI, F. ARAI AND Y. YAMAMURA

Table 1. Effect of diverse metal ions.

\begin{tabular}{cccc}
\hline Ion & $\mathrm{Et3Pb}^{+}$ & ${\mathrm{Et} 2 \mathrm{~Pb}^{2+}}^{2+}$ & $\mathrm{Pb}^{2+}$ \\
\hline $\mathrm{Ag}^{+}$ & 0.2 & $<0.1$ & 5 \\
$\mathrm{As}^{3+}$ & 1000 & 1000 & 1000 \\
$\mathrm{Be}^{2+}$ & 1000 & 1000 & 1000 \\
$\mathrm{Ca}^{2+}$ & 1000 & 1000 & 1000 \\
$\mathrm{Cd}^{2+}$ & 50 & 10 & 100 \\
$\mathrm{Co}^{2+}$ & 1000 & $<0.1$ & 0.5 \\
$\mathrm{Cr}^{6+}$ & 3 & 0.1 & \\
$\mathrm{Cu}^{2+}$ & 0.5 & $<0.1$ & 5 \\
$\mathrm{Fe}^{3+}$ & 10 & 2 & 5 \\
$\mathrm{Hg}^{2+}$ & 1000 & 10 & 1000 \\
$\mathrm{Mg}^{2+}$ & 1000 & 1000 & 10 \\
$\mathrm{Mn}^{2+}$ & 1000 & 5 & 0.5 \\
$\mathrm{Na}^{2+}$ & 100 & 1000 & 100 \\
$\mathrm{Ni}^{2+}$ & 1000 & 10 & 5 \\
$\mathrm{Zn}^{2+}$ & 3 & 5 & 10 \\
\hline
\end{tabular}

1) $\mathrm{Et} 3 \mathrm{~Pb}^{+}, \mathrm{Et} 2 \mathrm{~Pb}^{2+}$ and $\mathrm{Pb}^{2+} ; 0.5 \mu \mathrm{g} \mathrm{Pb}$

2) The values in the above table denote the number of times for each metal ion against the level of each lead when the level of latter was determined to be within $10 \%$ of the addition level.

$\mathrm{HNO}_{3}$. This solution was adjusted to $\mathrm{pH} 8$ with $\mathrm{NaOH}$ for use as the sample. In this instance, $\mathrm{Et}^{2} \mathrm{~Pb}^{2+}$ is not extracted with benzene.

\section{3-2. $E t 2 P b^{2+}$ in the urine}

After measuring $20 \mathrm{~m} l$ of a urine sample into a separating funnel, $4 \mathrm{~m} l$ of $60 \%$ $\mathrm{HClO}_{4}, 8 \mathrm{~g}$ of $\mathrm{NaCl}$ and $10 \mathrm{ml}$ of MIBK were added into the funnel; and the contents were then shaken vigorously for 10 minutes. After the mixture had been allowed to stand for 10 minutes, the MIBK layer containing $\mathrm{Et}_{3} \mathrm{~Pb}^{+}$was discarded, and the water layer was adjusted to $\mathrm{pH} 7$ with ammonia water. This solution was transferred into another separating funnel, and after the addition of $2 \mathrm{ml}$ of $3 \%$ sodium diethyldithiocarbamate (DDTC) and $10 \mathrm{ml}$ of MIBK, the mixture was shaken. The $\mathrm{Et} 2 \mathrm{~Pb}^{2+}$ in the MIBK layer was then back-extracted into $1 \% \mathrm{HNO}_{3}$. This solution was adjusted to $\mathrm{pH} 8$ with $\mathrm{NaOH}$ for use as the sample. In this instance, $\mathrm{Pb}^{2+}$ is also extracted. However, because of different reaction conditions for $\mathrm{Et}_{2} \mathrm{~Pb}^{2+}$ and $\mathrm{Pb}^{2+}$, only $\mathrm{Et}_{2} \mathrm{~Pb}^{2+}$ is detected.

\section{3-3. $P b^{2+}$ in the urine}

After measuring $20 \mathrm{~m} l$ of a urine sample into a separating funnel, the same procedure as described in 3-2 was accomplished; and the MIBK layer containing $E t 3 \mathrm{~Pb}^{+}$was discarded. The water layer was adjusted to $\mathrm{pH} 9.8$ with $\mathrm{NaOH}$, and then transferred 


\section{DETERMINATION OF ETHYLLEAD COMPOUNDS BY HYDRIDE GENERATION}

into another separating funnel. After the addition of $3 \mathrm{ml}$ of the GHA solution and 10 $\mathrm{m} l$ of MIBK, the mixture was shaken, and after it had been allowed to stand for 10 minutes, the MIBK layer containing $\mathrm{Et}_{2} \mathrm{~Pb}^{2+}$ was discarded. The water layer was adjusted to $\mathrm{pH} 7$ with $\mathrm{NaOH}$; and $2 \mathrm{~m} l$ of $3 \%$ DDTC and $10 \mathrm{~m} l$ of MIBK were added to extract $\mathrm{Pb}^{2+}$ into the MIBK layer. The $\mathrm{Pb}^{2+}$ in the MIBK layer was back-extracted into $1 \% \mathrm{HNO}_{3}$, and this extract was adjusted to $\mathrm{pH} 8$ with $\mathrm{NaOH}$ for use as the sample.

\section{Recovery rates, accuracies and sensitivities}

To $20 \mathrm{~m} l$ of a urine sample were added $20 \mu \mathrm{g} \mathrm{Pb}$ of $\mathrm{Et}_{3} \mathrm{~Pb}^{+}, 20 \mu \mathrm{g} \mathrm{Pb}$ of Et $2 \mathrm{~Pb}^{2+}$ and $20 \mu \mathrm{g} \mathrm{Pb}$ of $\mathrm{Pb}^{2+}$; assay samples were then prepared from the mixture by the extraction methods described in 3 above, and assayed by the standard procedure. Table 2 shows the recovery rates and coefficients of variation of the leads from 5 replications. $\mathrm{Et} 3 \mathrm{~Pb}^{+}$in the urine was directly determined without the extract procedure. Total lead in the urine was likewise determined directly. $\mathrm{Et}_{2} \mathrm{~Pb}^{2+}$ and $\mathrm{Pb}^{2+}$ in the urine were determined by the extraction methods. The recovery rate for $\mathrm{Pb}^{2+}$ was $91 \%$, but those for the other leads were as high as not less than $95 \%$. The coefficients of variation were $2.9 \%$ for total $\mathrm{Pb}, 5.6 \%$ for $\mathrm{Et} 3 \mathrm{~Pb}^{+}, 7.5 \%$ for $\mathrm{Et}_{2} \mathrm{~Pb}^{2+}$, and $2.1 \%$ for $\mathrm{Pb}^{2+}$ : this technique thus seems to have high reproducibility.

The detection limits of this technique proved to be $0.005 \mu \mathrm{g} \mathrm{Pb}$ for both $\mathrm{Et} 3 \mathrm{~Pb}^{+}$ and $\mathrm{Et}_{2} \mathrm{~Pb}^{2+}$, and $0.1 \mu \mathrm{g} \mathrm{Pb}$ for $\mathrm{Pb}^{2+}$. The calibration curves for the leads gave a satisfactory linear relation for the levels of not more than $1 \mu \mathrm{g} \mathrm{Pb}$, respectively.

Even if $\mathrm{Et}_{3} \mathrm{~Pb}^{+}, \mathrm{Et} 2 \mathrm{~Pb}^{2+}$ and $\mathrm{Pb}^{2+}$ are coexistent in a urine sample, the extraction methods described in 3 above permit only the target lead or leads to be determined.

Table 2. Recovery and coefficient of variation of leads from urine.

\begin{tabular}{lrrrr}
\hline & $\begin{array}{l}\text { Total } \\
\text { lead }\end{array}$ & $\mathrm{Et3Pb}^{+}$ & $\mathrm{Et2 \textrm {Pb } ^ { 2 + }}$ & $\mathrm{Pb}^{2+}$ \\
\hline Average recovery (\%) & 95.9 & 99.7 & 97.3 & 91.4 \\
Coefficient of variation (\%) & 2.9 & 5.6 & 7.5 & 2.1 \\
\hline
\end{tabular}

$$
\mathrm{n}=5
$$

\section{Conclusion}

A method utilizing hydride generation and atomic absorption spectrophotometry permitted rapid fractionation and determination of $\mathrm{Et}_{3} \mathrm{~Pb}^{+}, \mathrm{Et} 2 \mathrm{~Pb}^{2+}$ and $\mathrm{Pb}^{2+}$ in the urine with high sensitivities and accuracies by the use of the same system. The determination by this technique of leads in the urine of persons exposed to tetraethyllead permits the chemical species of the leads to be got hold of accurately.

Besides the assay of the urine for $\mathrm{Et}_{3} \mathrm{~Pb}^{+}, \mathrm{Et}_{2} \mathrm{~Pb}^{2+}, \mathrm{Pb}^{2+}$ and total lead, the assay of many other biological samples seems to be possible by the pretreatment of the samples similar to that of urine samples. 


\section{ACKNOWLEDGEMENTS}

The authors are grateful to Dr. Shin'ichi Imura, director of the Research Service Center, Toyo Soda Manufacturing Co., Nanyo-cho, Yamaguchi, for kind guidance in the present study.

The present study was supported in part by the Grant-in-Aid from the Japanese Ministry of Education in Scientific Research (fiscal 1979 and 1980).

\section{REFERENCES}

1) Calingaert, G., Shapiro, H., Dykstra, F.J. and Hess, L. (1948). J. Am. Chem. Soc., 70, 3902.

2) Arai, F., Yamamura, Y. and Yoshida, M. (1981). Jpn. J. Ind. Health, to be published. (In Japanese)

3) Henderson, S.R. and Snyder,, L.J. (1961). Anal, Chem., 33, 1172.

4) Bolanowska, W. (1968). Br. J. Ind. Med., 25, 203.

5) Imura, S., Fukutaka, K., Aoki, H. and Sakai, T. (1971). Bunseki Kagaku, 20, 704. (In Japanese)

6) Hayakawa, K. (1971) Jpn. J. Hyg., 26, 377.

7) Imura, S., Fukutaka, K. and Kawaguchi, T. (1969). Bunseki Kagaku, 18, 1008. (In Japanese)

8) Braman, R.S., Johnson, D.L., Foreback, C.D., Ammons, J.M. and Bricker, J.L. (1977). Anal. Chem., 49, 621.

9) Braman, R.S. and Tompkins, M.A. (1978). Anal. Chem., 51, 12.

10) Yamauchi, H. and Yamamura, Y. (1979). Jpn. J. Ind. Health, 21, 47. (In Japanese)

11) Yamauchi, H., Iwata, M. and Yamamura, Y. (1980). Jpn. J. Ind. Health, 22, 111. (In Japanese)

12) Jin, K., Taga, M., Yoshida, H. and Hikime, S. (1978). Bunseki Kagaku, 27, 759. (In Japanese)

13) Heap, R., Saunders, B.C. and Stacey, G.J. (1951). J. Chem. Soc., 658.

14) Imura, S. and Fukutaka, K. (1965). Bunseki Kagaku, 14, 1167. (In Japanese) 